\title{
Interior spaces as traces in Balzac's La Comédie humaine
}

\author{
Dominique Bauer ${ }^{1}$
}

ABSTRACT This article focuses on how Balzacian interiors and their dwellers signal a new experience and understanding of the past and the present that emerged during the Revolution and its aftermath. In this context, two interiors are analyzed: the interior of the Hôtel d'Esgrignon in Le Cabinet des Antiques and the antique shop passage in La Peau de chagrin. Both literary interiors in different ways embody traces of an "absent present" and constitute a solipsist mimesis of reciprocity between dweller and dwelling. These literary interiors signal fundamental aspects of a century that was marked by the loss of the past to history and by the experience of present time as but an elusive, fragile trace. Like the two sides of the same coin, this was also the time of vivification of absent images that are simulated, imitated in interiors of presentification, like the stereographic cabinet or the panoramic theatre. These interiors radicalize the traditional cabinet and its imagery, like Walter Benjamin's typification of the window shop and the panoramic theatre would show. The Hôtel d'Esgrignon substantiates an absence-less presence with reality. Balzac conceives the mimetic relationship between the cénacle des antiques and its Hôtel as a sophisticated subtext that reveals the illusionary nature of the ambition to establish such an absolute present. Those who reside in the Hôtel constitute the object-like and lifeless parody of a dynamics of representation played out and that reveals the fundamental absence they stand for. In La Peau de chagrin, isolated objects are fragmented, eclectic bits and pieces of representations that are vivified, and not imitated, by imagination. The cabinet as a place that is the objects it arranges and shows, is internalized as a mental space of imagination, of hyperbolic possibilities of representational assemblage. The hybridity of its visitor is that of imagination itself being represented. Here, Balzac points forward to a literary development in which spatial settings, par excellence that of a vast, fantastic, endless space, will become an image of (literary) representation itself. This paper is published as part of a collection on interiorities.

\footnotetext{
${ }^{1}$ Katholieke Universiteit Leuven, Gent, Belgium Correspondence: (e-mail: dominiquebauer07@gmail.com)
} 


\section{Balzacian interior spaces. Places, traces and representation} in a fragile present

n Balzac's novel Le Colonel Chabert, Hyacinthe Chabert, Colonel in the Imperial Guard and erroneously declared dead after the battle of Eylau (1807), lives in the house of an old Maréchal-des-logis, in the Rue du Petit-Banquier, in the peripheral and miserable faubourg Saint-Marceau. Unpaved, with deep ruts, the street is not easily accessible. The entrance to the house, hard to find, consists of two decrepit pilasters run into by coaches, and is situated between two walls "built with earth and bones"1. The dejected house itself, "one of those hovels comparable to nothing" ${ }^{\prime 2}$ and that would have a poetic beauty in the country, but are just completely dismal in Paris, finds itself at the back of a rather large courtyard. Although it is "only recently built, it gives the impression that is about to fall to ruin". ${ }^{3}$ The awkward construction, shabby, frail, "with mismatched and grotesquely places windows", is put together with second-hand materials, "none of which were used for their actual purpose". They are bits and pieces gathered from "demolitions that were taking place in Paris every day", something which in the portrayal of the house adds to the difficult urban setting, the awkward construction and its general out-of-placeness.

Its dweller Colonel Chabert, is portrayed as a fixed, immutable, near-dead and frozen character. When he sits waiting for the solicitor Derville, he is as perfectly immovable "as a wax figure of that cabinet of Curtius", his face, "pale, livid, as thin as a knife... was as the face of the dead. ${ }^{\text {" }}$ He is compared, as many other characters throughout the Comédie humaine, with a painting. With his body so completely hidden in the shadow, his head "could seem like a Rembrandt portrait without a frame" and the shadow cast on his face by his hat had a "grotesque effect... (that) threw into relief by contrast the white furrows, the cold wrinkles and the colourless tone of the corpse-like countenance". Chabert's depiction is that of the dramatic effect of two types of representation, of his likeness to a Rembrandt painting and of the contrasts effected by a shadow. Chabert is not to be distinguished from those effects and constitutes a being between a flesh and blood person and a wax figure, empirical presence and representation. Chabert resembles in this sense the Marquise de Listomère in Le Lys dans la vallée, who is "old like a cathedral, painted like a miniature". "She lives in her Hôtel as if Louis XV had not died" amidst "a society of fossilized bodies". ${ }^{8}$ In the same way he resembles the Marquis d'Esgringon in Le Cabinet des Antiques, that "admirable ruin", who has "the majesty of grand destroyed things". ${ }^{9}$ His sister, Armande d'Esgrignon, and their company that constitute "le cénacle du cabinet des antiques"(Balzac, 1976b, Vol. 4: 1020), are also hybrid creatures, lingering between subjectivity and objectivity.

Their loss of subjectivity is expressed in their corpse-like state, their mechanical appearance and their likeness to furniture and architectural surroundings. In the Comédie humaine, dwellers and dwellings, furniture, objects, landscapes and decor engage in a peculiar mimetic relationship. As Jacques Neefs points out, the dwelling that imitates its dweller is at the center of the Balzacian mimesis and constitutes the motif of his exposition of spaces. ${ }^{10}$ In Balzac's world of exterior, readable signs, the city, the landscape, the costume, the protagonist and the inner self seem to engage in constant reciprocal reflections, thus constituting a chain of refracted representations, passing from the exterior to the interior, to clothing, costumes, houses and rooms, from physiognomy to character, from aspect to self. The composition of Balzac's literary spaces likens in that respect also that of the characters themselves. The subject-object hybridity that marks Colonel Chabert and similar characters mentioned above, like the d'Esgrignons or the Marquise de Listomère, is at the same time also a representational hybridity. As has been mentioned above,
Chabert is both empirical presence and representational effect, and precisely in being such a hybrid creature, he is decaying, moribund, out of time and place.

In the Balzacian image of the interior space, the portrait of objects, of the hybrid or the out of time/place dweller may intertwine with the portrait of the dwellings in which they find themselves. The fact that they represent each other is one of the reasons why the theme of the imagery of interior spaces in the Comédie humaine is so captivating. A number of in-depth studies and analyses have already addressed various interesting interiors or types of interiors in Balzac's œuvre. Recently, also the volume Honoré de Balzac, Architecte D'Intérieurs has been published (Gautier, 2016). These may go into the strongly representational dimension of Balzac's imagery of interior spaces, such as Nathalie Preiss' analysis of the cabinet de curiosités in La Peau de chagrin, from "inventio" to "inventaire" (Preiss, 2016b: 230) or of the boudoir as a laboratory (Preiss, 2016a: 173-190). Furthermore, much attention has been paid to the encompassing mimetic relationship of physiognomy of dwellers and spaces. Houses, landscapes and urban zones bear physiognomic qualities, in the same way that people's physical appearance and costumes do. In that sense, aspect, class, dwelling, like the "appearance ('physionomie') of a house" as it is called in Eugénie Grandet (Balzac, 2009: 3), furniture and objects become interchangeable signs with a distinctively spatial dimension. In this sense, as Owen Heathcote maintains in his article on the desk in Les Employés, the immutability of the cleric is that of his desk, "like a second skin": "Le bureau est la copie de l'employé" (Heathcote, 2013: 10). The second skin value that is thus attributed to a piece of furniture denotes again the representational value of Balzacian interior space. In this sense, as John O'Connor argued in his analysis of La Fille aux yeux d'or, a woman, like Paquita Valdès, can become a microcosm of her boudoir, while it is not clear where she ends and the room begins (O'Connor, 1977: 78).

Within this larger mimetic framework, the interior is mainly conceived as a liminal interior, ambiguous and caught up in a dynamics of exterior and interior, openness and closedness. The latter ambiguity is studied in close relationship with the themes of vision, seeing and being seen, and voyeurism. These are all primarily connected with the literary theme of representation as a part of the dynamics of that liminal interior. Especially the boudoir, between the public salon and the private bedroom, between plain sight and the (deficient) escape from alien gazes, has been studied in a number of publications (Fröhlich, 1981; Delon, 1999; idem, 1998; Richer, 2012: 26; idem, 2004; Preiss, 2016a). Finally, the general hybridity of Balzacian spaces between openness and closedness, public and private forms of exposure, has led researchers to characterize the Balzacian space also as a heterotope/sociotope (Heathcote, 2013), or as a heteroptope/ "espace-carrefour" (Ebguy, 2004 ).

Tying in with the close connection between aspects of liminality, representation and subtextual strategies, this contribution focuses on one aspect in particular of the Balzacian interior with its hybrid, object or art-like dweller. Through a close reading strategy, the cabinet mystérieux in La Peau de chagrin and the interior of the Hôtel d'Esgrignon of Le Cabinet des Antiques are understood as different subtexts to a new attitude towards past, present and future. This attitude arose amidst the cultural shockwaves that marked the French Revolution and its aftermath. It reveals a sense of time speeding up, of a deep historical experience of the past as other, different and irremediably over, of an elusive present that slips through the contemporaries' fingers like sand, and of unknown possible futures. In this context, new ways of spatial experience and meaning emerge and of revealing subjectivity in an imagery of spaces. This is the world of Colonel Chabert who fails to escape the oblivion and absence in which he 
is trapped, living in a house that itself is reminiscent of a city where the past is demolished every day, "démolitions qui se font journellement dans Paris". It is also that of the closed universe of the "cenacle des antiques" in Le Cabinet des Antiques, relics of another age and merging with the furniture in a movement of objectification. Hybrid, art or object-like, they are traces that barely exist in the present, almost disintegrating, crumbling under the weight of an absent past.

It will be shown that the interior of Le Cabinet des Antiques and the magasin de curiosités in La Peau de chagrin, function as refracted reflections of the ambiguities of the changing experience and understanding of the past, present and future dimensions of reality. Both Balzacian interiors deal with the intimate relationship between the urge of presentification and absence after the culture shock of the French Revolution. The cabinet des Antiques proves itself as a closed, self-referential world that is irremediably over, with its frozen time in the yet eternal and objectified present of things. Within the logic of the cabinet, le cabinet des antiques remains a trace without a present. Also the magasin des curiosités in La Peau de chagrin tackles the problem of presentification and seemingly inscribes itself in the same logic of the trace. The antique shop, loaded with the worn iconology of the traditional cabinet, and with its vast spaces, inscribes itself in a particular kind of cabinet imagery that may also be found in the work of Benjamin Zix, who pictures Dominique-Vivant Denon in his fantastic cabinet, or in that of Joseph M. Gandy who depicts John Soane's architectural cabinet. It will be shown that by doing so, Balzac points forward to the new role of, sometimes hyperbolic, imagination that is very different from the visual mimicries that are increasingly conceived to convey the present state things in a neutral, documentary way. In La Peau de chagrin, the cabinet is internalized as the mental realm, and its vast spaces, like the subsequent literary development shows, may become an image of literary representation itself.

\section{A modern sense of historicity. The lost past and its recuperation}

The end of the Ancien régime and the turmoil of the Revolution marked the beginning of an age of dispersion and fragmentation, of lands and people, but also of objects and buildings, through pillaging, confiscation, sales, and social and territorial reorganization (Watson, 2000: 9-16), like the brocade curtains in $\mathrm{La}$ Rabouilleuse that were "stolen from the bed of some commendatory abbot (Balzac, 1976: 165)". The new century was quite literally washed over by isolated things, by fragmented bits and pieces and by bibelots, cut off from their original setting. These were characteristic of a world that was confronted, in an unprecedented way, with a past that was severed from the present, a past that had become unique, different and fundamentally other. As Koselleck pointed out in his analysis of the modern concept of history, the past could no longer function as a traditional, repetitive exemplum. History had become singular and "verzeitlicht" (Koselleck, 1988: 47; 62). Following Koselleck, Peter Fritzche shows in his Stranded in the Present. Modern time and the Melancholy of History that past events had become unique moments, caught in their particular time frame, whereas the present had become elusive, ungraspable and nearabsent (Fritzsche, 2004: 15-54). Hartog, in his Régimes d'historicité. Présentéisme et experiences $d u$ temps, pointed out in this respect how the past could no longer be fixed, because of the acceleration of time that in an exemplary way was experienced by Chateaubriand: "Les événements couraient plus vite que ma plume" (Hartog, 2012:116). In this framework of the present slipping through one's fingers, Chateaubriand talks in his Mémoires d'outre-tombe about himself as if he is already gone.
As Hartog mentions in his interpretation of Chateaubriand's Memoires projects, "Le travail du temps est ce qui fait qu'on s'absente de soi, jusqu'à l'ultime absence;..." (Hartog, 2012: 125). The elusiveness of the present resides in that it had become a trace that was characterized by a fundamental dimension of absence. As Jan-Henrik Witthaus argues in his analysis of Balzac's La Peau de chagrin, when the fragment, or the ruin, becomes the point of departure of the here and now, the present crumbles under the weight of the past it refers to while it displaces itself in the future (Witthaus, 2013: 234-235.)

This loss of origins implied a profound sense of absence of meaning and of identity that went with the visual loss of the past in a world of vastly changing land-and cityscapes and socioeconomical stratification, already in effect before the days of Haussmannization. In this literally fragmented universe, bits and pieces of a disappearing world, like "types" of houses for example, or views of quintessential landscapes were "saved" and (re)created into the presence of an often idealized lost past against the cultural wave of loss and demolition. Very specifically in the case of regionalist movements, these endeavours were also directed against the new world after the Revolution with its abstract citoyenneté. The Museon Arlaten, the Provençal pavilion and the literary /lexicographic projects of the Provençal regionalist Frederic Mistral are very illustrative in this respect.

The example of Mistral, like that of various other regionalists who opposed modern society, very much illustrates Ankersmit's understanding of rupture as the source of historical experience and the idea that "discarded identities", as he calls them, "will remain present only as an absence," while "dissociated pasts" are associated with an idyllic pre-historical and natural world. "Myths are those parts of our collective past that we refuse to historize: A mythical past is taken outside the course of history and made immune to historical (re-)interpretation." (Ankersmit, 2005: 367-368). With Mistral and others, the materiality of places and things in which pre-modern culture resides has mythical status and seems indeed to resist representation and historical interpretation. Mistral's mythical dimension of matter, of the material object, of topology and the concrete material place in which the exhaustive essence and image of Provençal culture was embedded, thus resonates the symbolic dimension of the object, denuded "dans sa materialité" during the Revolution, as Pascal Griener termed it, that would gain evocative momentum in the museum (Griener, 2010: 150). The myth of the ideal pre-modern world, epitomized in the idealized ritual of domestic life, is rooted in time immemorial and is materially revived in his museum, where one finds all "the living life ('la vie vivante'), like in a reliquary", as he wrote in the Armana Prouvençau in 1900 (Pasquini, 1988: 265). ${ }^{11}$ This strategy is par excellence applied in the Provençal Pavilion at the 1906 Exposition Coloniale in Marseille. From within the center of a panoramic theatre, designed like a quintessential Provençal mas, one could admire amazingly wellaccomplished and life-like stereographic views of iconic Provençal landscapes through interior "windows", like for example the Pont Saint-Bénézet or a market in Aix-en-Provence. A spatially internalized landscape was thus preserved in this interior space as a radical and contradictory lieu de mémoire, in terms of the ambiguous living life, the here and now of a relic, to retake this phrase from the Armana. In the same context, Mistral's Museon Arlaten would later shelter the very last cabane of Salin-de-Giraud (Galtier, 1977: 17-18), thus preserving objects and buildings in situ, in their material, tangible place. Mistral's Provençal pavilion thus epitomizes the relation between spectator, space, the visual and the tangible in the panoramic theatre. He did so in a way that was direct, that constituted a spectacular simulation that effected an overwhelming as-if-you-were-really-there-experience. As D'Arcy Wood argues in his The Shock of the Real, this that was precisely that which characterized the visual spectacle. ${ }^{12}$ 
As Isabel Kranz notes, Walter Benjamin underlines the closed nature of these interiors, -the panoramic theatre is essentially windowless for example-, in his analysis of the shop window and the panoramic theatre in the Passagenwerk. As a "Haus" it constitutes a "Bildraum" (image space) in which also the spectator is integrated, caught up in the spectacular presence of vast views. In the Benjaminian panoramic theatre and the world of shop windows, the spectator is included in the image space. ${ }^{13}$ Furthermore, these spaces also offer a complete image of the world re-enacted, to the extent that they evoked, in Benjamin's eyes, a more perfect Paris than the real one beyond the walls of the theatre (Kranz, 2012: 29; 42). In Benjamin's analysis, these spaces align with and continue the logic of the cabinet of curiosities that from its very pre-modern outset was conceived as a small-scale copy of the cosmos, showing through its arrangement and scenography of objects a whole universe, and was furthermore characterized by a relationship of absence-less immediacy with its occupiers. ${ }^{14}$ In the age of the modern concept to which Benjamin's account testifies, immediacy has turned into a dynamics of presentification.

The Museon Arlaten and the Provençal pavilion show this combination of directness, radical presence, inclusion of the spectator and the completeness of the world imaged as it is analyzed by Benjamin. The representational nature of things is "forgotten," also in the sense that the barriers between the world represented-or rather, "simulated"-with the space of the spectator are undone in an experience of direct contact, and therefore direct material presence. ${ }^{15}$ Concrete places and the material "lieu" become topographical cabinet-spaces, as in the case of the cabane in the Museon Arlaten, that materialize and show the past, and in which bygone traditions and time immemorial are anchored and made present. ${ }^{16}$

In this context, traces of the past become an almost tangible present, and constitute a dam against the absence in loss. The experience and knowledge of a far away past is spatialized and materialized in the topographical in situ approach to the origin of objects and buildings. Perhaps the most salient example of this urge for vivification was the use of mannequins, like in the Museon Arlaten, sometimes set in genuine, pieced together interiors or dioramic volumes (Degroff, 2012). Armand Landrin, co- conservator of the ethnographic Trocadéro museum in Paris and very much fascinated by the French pre-modern world, writes that these mannequins, that he uses in his own Salle de France in the Trocadéro, should be "modeled after nature in order to give an exact idea of the type of the region (Landrin, 1889: 295)." 17 These mannequins and tableaus were meant to evoke in a very lifelike, concrete way the essential pre-industrial human type of various indigenous regional or foreign cultures, rooted in time immemorial. These were thought to be very popular with the general public, overwhelmed by this mass-entertainment "shock of the real", to use the title of D'Arcy Wood's monograph. ${ }^{18}$

\section{Absence and hybrid dwellers. Le Cabinet des Antiques}

In Herbert G. Wells' 1895 The Time Machine, time travel is possible because we are able "to recall an incident very vividly," and go back "to the moment of its occurrence", which makes us "absent-minded" (Wells, 2005: 6). As a result, the present is absent when we travel in time. In his already mentioned analysis of the staging of time and space in the antique shop in La Peau de chagrin, Jan-Henrik Witthaus argues that when the fragment or the ruin (examples of what we have indicated as trace) becomes the point of departure of the here and now (as in what we have called presentification). The present crumbles under the weight of the past to which it refers while it displaces itself into the future (Witthaus, 2013: 234-235). Either way, pure, exclusive presence that shuns all absence seems to effect its own impossibility. Pure presence effects absence. Throughout the development of the cabinet/interior imageries, this evolution was shaped by the absence effected by perception and self-perception as an alienating agency, causing black holes in the protagonists' consciousness. These become, in various degrees, hybrid creatures between pure presence/subjectivity on the one hand and absence/ loss of being in objectivity on the other (Bauer, 2016: 92-104).

Hybrid creatures, lingering between subjectivity and objectivity, figure par excellence in the notorious description of the cenacle of "antiquities" in Le Cabinet des Antiques, consisting of the Marquis d'Esgrignon, his sister, Mlle Armande and those of like mind. Throughout the mimetic reciprocity between people, decor, things and spaces that characterizes Balzac's œuvre, it is sometimes hard to know where the furniture or decor end and people begin and which "effects" are caused by either people or by their material surroundings (Richard, 1970). This is especially the case in some of the passages where dwellers melt with portraits and with objects of art or are described as if they are themselves artistic objects. Dwellers may be part of the "tableau" that surrounds them, be themselves portrait-like, or even quite literally appear to be stepping out of a portrait. In La Femme de trente ans (1828-1842) for example, Mme d'Aiglemont "would have made a curious tableau for a poet passing by on the boulevard", her physiognomy would make one stop and think for a moment, as one would do in a museum in front of "that sublime head in which Murillo depicted maternal pain". She is one of those "human figures that are despotic images that speak to you, interrogate you and answer your secret thoughts"19

Passages such as these abound in Balzac's work. Within the scope of this contribution, it is not possible to treat this issue extensively, but the fact that in the Comédie humaine a character, or a space, is very poignantly a character or a space that is (painterly) represented and therefore always has a subtextual dimension, strongly adds to the mixture of actual characters and artistic representation, most obviously in the case of the portrait (Vannier, 1972: 55-57). In Balzac's literary universe, objects intertwine with representation. Objects-representations play a dominant role in Balzac's interiors. The piled up objects that characterize many of Balzac's interiors constitute what José-Luis Diaz calls a chaos or a disorder that "nevertheless organizes itself as a grotesque tableau." Diaz refers in this respect to the "chaos of antiquities" in La Peau de chagrin (1831) or the "jumble that no description could put in place" in La Rabouilleuse (1841-1842) (Diaz, 2012: 87). The relation between "chaos", the "grotesque" or the "bizarre", that clearly opposes the well-organized interior in other passages, like cousin Pons' museum in Le Cousin Pons, comes forward in various instances throughout the Comédie humaine. Like characters, interiors are also highly representational, they are tableaux, arranged in some way and with both aesthetic and psychological effects.

The interesting point about the cenacle of antiquities in $L e$ Cabinet des Antiques, is that the representational nature of this portrait, just like that of Le Colonel Chabert, reveals its out-ofplaceness, its hybrid, object-like nature as a trace of the past. By doing so, by showing traces in this way, Balzac's portrait of the cabinet des antiques, testifies to a new experience of the bygone past and the fragile present. The latter is but a trace of an inaccessible, strange past, characterized by otherness. With Balzac, representation, hybridity, the loss of subjectivity and the objectification of dwellers, thus seem to echo notions of absence and new attitudes mentioned towards history in the broader culture of his day. Furthermore, the image of an internally closed cabinet, its transparency to the gaze beyond and its submission to voyeurism that are central to Balzac's portrait of the cabinet des antiques, highlights one of the strongest mechanisms of 
objectification that characterizes the history of the imagery of interior spaces: the gaze that is inherent to representation. 20

The Marquis d'Esgrignon, that "admirable ruin" who had "all the majesty of grand destroyed things", and his sister Mlle Armande are highly objectified, hybrid subjects. They are set in an interior, in a perfect mimetic relationship with the objects and the decor of the Hôtel d'Esgrignon that are expressions of a world in which "L'empereur" is only "monsieur de Buoanaparte" and "le Département" has always been "la Province" (Balzac, 1976b, vol. 4: 974). The Hôtel d'Esgrignon is described in the way it lives on in the memory of Emile Blondet. It is essentially an image of a memory of a then 12-year-old boy and in that sense a representation of a representation. ${ }^{21}$ The salon, highly significantly, is like "a glass cage," "un cage de ver" (Balzac, 1976b, Vol. 4: 975). When in town it was impossible not to take a look at it. To Emile Blondet, "it was one of those curiosities that found themselves on the boundaries between the real and the fantastic, when one thought about it later".22 The out-of-placeness of buildings, their loss of coherence and proportion, is highly reminiscent of the many Hôtels and Châteaux that were stripped of their original purpose during the Revolution. In Le Cabinet des Antiques, this disintegration runs right through the decrepit, uncanny, puppetlike characters themselves. The out-of-placeness of the wainscot, that breathes and represents the absence of the once chambre des délibérations, seamlessly extends into the lined up dowagers who sit under it, mummy-like creatures that in their turn also represent an absent, fatally past world. The fact that the d'Esgrignon salon is a glass house, a cabinet closed from the interior, but transparent from the outside as an object of voyeuristic attention, strongly underlines the objectified nature of the "cénacle du Cabinet des Antiquités" (Balzac, 1976b, Vol. 4: 1020). Vision and voyeurism, so central to the development of the imagery of the cabinet-interior and the objectification of its dwellers, find a very outspoken expression in the theme of the glasshouse in nineteenth-century literature. ${ }^{23}$

In Le Cabinet des Antiques, this context of exposure and objectification joins and reinforces the role played by out-of-place, decrepit or dusty objects, and the architectural setting of disintegration and re-arrangement. Some of the remains of the furniture of the Esgrignon Château, that was lost to the family during the Revolution, had filled the disproportionally large salon. The salon found itself among other rooms that had served very different purposes before the Marquis and his sister came to live there. The dining room was once the chambre des délibérations, with its wainscot and the "eight or ten dowagers, some with shaky heads and others dried and black like mommies." 24 Never afterwards had Emile Blondel, "neither with the living, nor with the dying", seen such pale grey eyes or such frightening vivacity in black eyes' than he had seen there. And "neither Maturin nor Hoffmann ... had ever inspired in him more horror than the automatic movements of those hooked bodies". ${ }^{25}$ In the uncanny image of the doll-like dowagers with their wobbling heads, the dynamics of an isolated, internal movement back and forth between dwellers and dwelling in a game of exposing, representing, seeing, is stretched out to a parody. In the logic of the cabinet, the present in representation reveals itself as objectification and as a fundamental absence and loss of subjectivity.

\section{The past made present in ecstatic imagination. The antique shop in La Peau de chagrin}

In La Peau de chagrin, the desperate Raphael de Valentin, who is on his way to commit suicide after losing what remains of his savings in a gambling house, somewhat by accident ends up in a peculiar antique shop. At first sight the storerooms present a "chaotic picture ('tableau'), in which all works, human and divine, were jumbled together" (Balzac, 2012: 13). Raphael is overwhelmed by a spectacle in which "the origins of the world and the events of yesterday were grotesquely jolly bedfellows (Balzac, 2012: 14)". To this "chaos of antiquities", "all the countries on earth seemed to have provided some remnants of their sciences, a sample of their art. It was a kind of philosophical midden in which nothing was missing (Balzac, 2012: 14)". Raphael enters a space in which "he sank once more into a state of dizziness ('Il retomba bientôt dans ses vertiges') (Balzac, 2012: 13)”.

Raphael's psychological state reflects the very same vertiginous nature of the storerooms, and indicates the start of a mimetic dialogue between the dweller and his interior. From its very outset, the antique shop comes forward as a solipsist, subjective world, in which the representational and psychological dimensions of objects constantly interconnect, and the spatial boundaries between the sensorially overwhelmed visitor and the objects fade. Both dynamics are intimately intertwined. Various elements in Balzac's account point in this direction. From the beginning, the shop explicitly presents itself to Raphael as a "picture" (a "tableau"). The reader thus enters an interior that is actually an image of (a) representation, painted by Balzac. Its description is the development of the dynamics of that image, and in that sense has a subtextual dimension. The tangled jumble of objects that fill the storerooms are described in terms of their capacity to reflect, either completely, in a fragmented or multifaceted way, or partially. The range of these reflections goes from the Cuvier-like isolated sample from which whole worlds can be read to Raphael's actual envisioning of these worlds in his mind's eye. Paraphrasing the fundamental nature of the cabinet as a dynamics of representation, the three initial rooms are like "a mirror of many facts, each one representing a different world ('représentait un monde') (Balzac, 2012: 14)." In a mimetic back and forth, the multiplicity of "effects" from the objects matches the overwhelming multiplicity of sensorial stimuli that inundate Raphael. The antique shop is a machine of vivification, that expresses itself through various means of direct expression, hinting at simulation rather than at actual representation: A marble statue "speaks" to Raphael, a Chinese monster "strikes", Raphael "sees" the conquests of Alexander the Great on a cameo (Balzac, 2012: 15-16).

On the one hand, the antique shop is highly reminiscent of the obsession of the age to cast out absence and to represent an entire and therefore enclosed world, exhaustively, perfectly. Nowhere in the novel is the endeavour more expressed, perhaps, than in Balzac's bold statement that Cuvier "brings the void ('le néant') to life again (Balzac, 2012: 19)." There is no named, known, conscious "beyond" beyond the interior, that thus functions as a metaphor for a world that is present in an exhaustive way to the spectator/poet. Yet, on the other hand, the antique shop is not just a literary image that allows Balzac to flesh out the worn dynamics of representation in the imagery of the cabinet, like he does in Le Cabinet des antiques. The universe in which marble statues speak, and entire battlefields can be witnessed from a cameo in an architecture of vast and seemingly endless spaces that is suggested, like "an endless poem" (Balzac, 2012: 16), signals the heightened sense of subjectivity, in those "palaces of Ecstasy" (Balzac, 2012: 15), of imagination against what is merely visually, materially reenacted. ${ }^{26}$ In this context, Balzac comes forward as the sharp-eyed chronicler of the emerging taste for historical objects, like in the case of Du Sommerard's Musée de Cluny, that "was to stimulate the imagination not through words on the page, but through the presence of material objects", as Stephen Bann notes (Bann, 2011: 27).

Echoing the nineteenth century's chaotic universe of dispersed and piled up things and the aesthetic marvel, the attraction of the bizarre, of infinite spaces that substantiate the endless possibilities 
of imagination, and the thrill of the tangible presence of lost worlds and cultures, "these monstrous tableaux were subjected to a thousand accidents of light by the odd multitude of reflections... (Balzac, 2012: 14)". A thousand accidents, a multitude,... in Balzac's hyperbolic description, Raphael's heightened and exhausted sensitivity ties in with the vastness of the antique shop and the vertiginous state of its visitor that mirror each other. These literary connections also come forward in other architectural settings in art and literature involving seemingly infinite spaces, and in which a very similar relationship of reflection between dweller and dwelling also occurs. This type of cabinet representation, of with iconological examples had already been produced in the eighteenth century ${ }^{27}$, communicate in Balzac a hyperbolic, even potentially maddening imagination, overstretched by too many images, like those that constitute an entire nation, "which is too overwhelming for one man" (Balzac, 2012: 16). This appearance of imagination caught in the spatial logic of the cabinet constitutes the core of Balzac's literary antique shop, which both ties him in with the contemporary cabinet representation in art and with the development of spatial imageries that will operate as subtexts to literary representation itself.

Balzac's antique shop was not alone on the Quai Voltaire: so, too, was the cabinet-home of Dominique-Vivant Denon, aesthete, libertine, diplomate, archeologist, egyptologist and director of the Musée Napoléon (the Louvre) (Mauriès: 87-104; Spiegel, 2000:170-174). ${ }^{28}$ His self-representation through portraits, medallions and statuettes in the cabinet-home where he also lived expanded the representational logic of the cabinet and its hybrid dwellers beyond the page. As has been mentioned, elements of this logic of representation and the "danger" of hybridization that lurked there for the dweller, also come forward in Balzac's literary account. At the same time, with Denon too we find the imagery of the vast space. In Benjamin Zix's famous 1811 painting Portrait allégorique de Dominique-Vivant Denon (Mauriès, 2002, 199-201), Denon is depicted amidst an abundant number of objects that reflect his interests and adventures. The composition of the painting suggests a vast space, through the presence of a repetitive tangle of arcades that give the impression of leading everywhere, and through the application of multiple perspectives that enlarge the space. These resonate in Balzac's suggestion of endless rooms-upon-rooms and "multiple angles and numerous twists" (Balzac, 2012, 14). This representation of the cabinet mixes reminiscences of the premodern cabinet, like the bizarre, the exotic, the magical and the mysterious that become hyperbolic psychological states of mind, with a subjectivist experience of the world caught in the vast, seemingly endless spaces of a cabinet more fantastic than ever.

\section{Conclusion}

In Le cabinet des antiques, dealing with a social class that belonged to the past, the present in representation is revealed to be a fundamental absence. In La Peau de chagrin, that depicts the cabinet/collectionneur of the Napoleonic age and of the Restoration, Balzac directly addresses literary discourse and representation. Objects are fragmented, eclectic bits and pieces of the representations of worlds that are completed, organized and internalized by an imagination that vivifies, rather than imitates them. The cabinet as a place of objects, as a place that is the objects it arranges and shows, is thus internalized as a mental space of imagination, of hyperbolic possibilities of representational assemblage. Raphael's vertiginous state is also that of the cabinet mystérieux. The hybridity of Raphael who is "like those curious objects, neither completely dead, nor completely alive" (Balzac, 2012: 17), is that of imagination itself being represented, objectified.
Balzac anticipates a literary development in which spatial settings, the vast, fantastic, endless space par excellence becomes an image of representation itself. This is, for example, the case in Galdós' later novel La Sombra (1870) which very much recalls the description of the antique shop in La Peau de chagrin. Its protagonist, don Anselmo, a weird and seemingly insane alchemist, a clear reference to the cabinet iconology, is overwhelmed and tortured by phantasy, by too many stories that are all implausible. This phantasy is substantiated by Galdós in don Anselmo's father's enormous palace, “a delirium symbolized in opulence, the true hyperbolic aesthetics"(Galdós, 2011, 36). ${ }^{29}$ With Galdós, fantastic, eclectic architecture, that blends all ages and styles in a seemingly vast endless space, very poignantly concerns a subtext that seemingly undermines the very possibility of literature to offer anything else but the babbling of a madman. In this sense, the image of a vast space filled with objects and eclectic architecture not only communicates subjective imagination, but may become the very image of literary representation itself.

\section{Notes}

1 Balzac, 1959, Vol. 5: 53: "entre deux murs bâtis avec des ossements et de la terre". 2 Balzac, 1959, Vol. 5: 53: “une maison, si toutefois ce nom convient à l'une de ces masures bâties dans les faubourg de Paris, et qui ne sont comparables à rien".

3 Balzac, 1959, Vol. 5: 53-54: "Quoique récemment construite, cette maison semblait près de tomber en ruine".

4 Balzac, 1959, Vol. 5: 54: "Les fenêtres ne se ressemblaient point entre elles et se trouvaient bizarrement placées... Aucun des matériaux n'y avait eu sa vraie destination".

5 Balzac, 1959, Vol. 5: 54: "Ils provenaient tous des démolitions qui se font journellement dans Paris".

6 Balzac, 1959, Vol. 5: 36: "Le Colonel Chabert était aussi parfaitement immobile que peut l'être une figure de cire de ce cabinet de Curtius... Le visage pâle, livide, et en lame de couteau, ..."

7 Balzac, 1959, Vol. 5: 37: "un portrait de Rembrandt, sans cadre...Les bords du chapeau qui couvrait le front du vieillard projetaient un sillon noir sur le haut du visage. Cet effet bizarre, quoique naturel, faisait ressortir, par la brusquerie du contraste, les rides blanches, les sinuosités froides, le sentiment décoloré de cette physionomie cadavéreuse."

8 Balzac, 1978, vol 9: 979: "La marquise de Listomère... Vieille comme une cathédrale, peinte comme une miniature,... elle vivait dans son Hôtel comme si Louis XV ne fût pas mort, et ne voyait (qu'une)... société de corps fossiles..."

9 Balzac, 1967, Vol. 4: 975: "Cette admirable ruine avait toute la majesté des grandes choses détruites."

10 As Balzac reveals in Le Curé du village: "Pour une loi singulière, toute imite dans une maison celui qui y règne, son esprit y plane," a law that according to Jacques Neefs is "at the center of Balzacian mimesis and constitutes the motif of his exposition of spaces, decors and things as signs and as effects of a legible truth.” (Neefs, 2004: 117)

11 On time immemorial and the representation of culture with Mistral, see also: Bauer: forthcoming.

12 D'Arcy Wood, 2002, esp. 102-106. D'Arcy Wood very interestingly quotes in this context Quatremère de Quincy who remarked, on Pierre Prévost's Panorama of Athens in Paris, that 'the precious remains of antiquity of the city were rendered with a verisimilitude that seemed to dispense with the need to actually see the originals (D’Arcy Wood, 2002: 103).

13 On Panorama as an in this sense comprehensive and direct form of representation that integrates the spectator in its dynamics, see furthermore Meisel, 1983: 62.

14 On these fundamental characteristics of the cabinet, see Patrick Mauriès' seminal study: Mauriès, 2002: 8-44 and furthermore Haag, 2013: 9-20 (on the Viennese Kunstkammer), Davenne, 2004: 87-107; 111-122 (on closedness and arrangement), Trébosc, 2008: 67-75 (on arrangement, exposition and representation) and also Marrache-Gouraud, 2008: 139-148. On the development of the imagery of the cabinet in literature: esp. 48-65. On the importance of life-likeness and imitation, of interior, microcosm, miniatures and theatrum mundi (which are vital aspects of the traditional cabinet) in the more general, early development of protocinematographic devices of which the panorama would be one, see also: Altick, 1978: esp. 50-63 and also, on the need of horizon and limit (which is also fundamental in early-modern cabinet iconology) in this kind of perception: Oettermann: 9-17

15 Another good example, illustrative of the various aspects treated in Mistral's projects, but that cannot be fully fleshed out within the scope of this article is the Musée d'ethnographie du Trocadéro. Here, too, there was a lack of boundaries between the spectator and the museum space and objects. Nina Dias in her brilliant study of the museum states for example: "Aucune barrière ne séparait le visiteur des objects qui 
étaient exposés à son regard... pour lui rappeler que ce qu'il voyait était de l'ordre de la représentation et non pas de la réalité": Dias, 2004, 203.

16 In this respect, Mistral's in situ approach fits in with the approach he also deploys in his Provençal Dictionary Le Trésor du Félibrige, in which stories, legends, beliefs and customs are tied in with longs lists of concrete places, all of which together furthermore had to represent the entirety of Provençal culture: Bouvier, 1986: 5-17.

17 In the same way, Emile Marignan, who worked with Frédéric Mistral in the Museon Arlaten in Arles, requested that people send in "photographs", "hair samples", "moldings of heads and hands", "photographs and moldings of women's bosoms": Marignan, 1896, 5: "Photographies... -Moulages de têtes et mains-Moulages et photographies de poitrines de femmes-Échantillons de cheveux,..."

18 As was mentioned in a description of the Trocadéro museum in the 1886 Dictionnaire encyclopédique et biographique de l'industrie et des arts industriels: (on the Breton interior in the Salle de France) (my underlining): "ces moulages en cire colorée qui représentent différents types sauvages... et dans la grande salle, ..., en un intérieur breton de grandeur naturelle, frappant de vérité. Tout y est, pots, lits en forme d'armoires de bois ouvragé. Ce décor, très bien réglé, a le don d'attirer la foule," quoted in Noël, 1987: 146.

19 Balzac, 1976c, Vol. 3: 1205: "Cette femme... eût été, pour quelque poète passant sur le boulevard, un tableau curieux... Elle était un de ces types qui, entre mille physionomies dédaigneuses... vous arrêtent un moment, vous font penser, comme entre mille tableaux d'un musée, vous êtes fortement impressionné, soit par la tête sublime où Murillo peignit la douleur maternelle... certaines figures humaines sont de despotiques images qui vous parlent, vous interrogent, qui répondent à vos pensées secrètes,..."

20 For a historical overview of this development, see Bauer, 2016: 48-65.

21 A very similar type of description, combining painting and fossilization is also found, in a few lines, in Le lys dans la vallée, where the marquise de Listomère is also "old like a cathedral, painted like a miniature." "She lived in her Hôtel, as if Louis XV had not died," seeing only a "society of fossilized bodies."...: Balzac, 1978, Vol. 9: 979: "La marquise de Listomère... Vieille comme une cathédrale, peinte comme une miniature,... elle vivait dans son Hôtel comme si Louis XV ne fût pas mort, et ne voyait que... société de corps fossiles..."

22 Balzac, 1967b, 1976a,b, c, Vol. 4: 975: "Cette pièce me sembla toujours,... être une de ces curiosités rares qui se trouvent plus tard, quand on y songe, sur les limites du réel et du fantastique,..."

23 On the "glass cage" / "glass house" as similar tools of exposition, objectification or dehumanization with Zola (the mannequin in Au bonheur des dames, the charcuterie display in Le ventre de Paris), Balzac and Jules Verne (In Les cinq millions de la Gégum, "Herr Schulze is glass-enclosed and transformed into an object observable in vitro): Hamon, 1992, 173-174. In Balzac, this metaphor of invasive voyeurism fits with other secluded and yet transparent interiors that embody seeing and being seen, such as the already mentioned boudoir, that is essentially also a place of surveillance. As Jacques Neefs pointed out regarding the boudoir in La cousine Bette, this space is negatively defined as "une scénographie qui circonscrit l"espace privé au bord des regard et des intrusions" (Neefs, 2004: 116). The closedness of the salon d'Esgrignon is dissolved by the visual transparency effected by the glass. The boudoir, like other Balzacian spaces in which one could supposedly hide from the gazes of others, is internally only loosely separated from other spaces. In La cousine Bette (1846), for example, the porous boudoir is caught up in a dynamic flux of moving back and forth between spaces. Both in this novel and again in Ferragus (1834), these spaces have become ambiguous look-outs or even voyeuristic gate-ways. In Ferragus for example, the invisible opening in which Jules hides is hard to notice from the outside: Balzac, 1977, Vol. 5: 874:"Cette ouverture se trouvait, dans l'une et l'autre pièce, au-dessus d'une armoire..., et il était fort difficile d'apercevoir dans l'ombre cette espèce de meurtrière."

24 Balzac, 1976b, Vol. 4: 976: "huit ou dix douairières, les unes au chef branlant, les autres desséchées et noires comme des momies."

25 Balzac, 1976b, Vol. 4: 976: “je n’ai jamais plus retrouvé nulle part, ni chez les mourants, ni chez les vivants, la pâleur de certains yeux gris, l'effrayante vivacité de quelques yeux noirs... Enfin, ni Maturin ni Hoffmann,... ne m’ont causé l'épouvante que me causèrent les mouvements automatiques de ces corps busqués."

26 As D'Arcy Wood maintains in The Shock of the Real, to the elite, sight in the panoramic theatre was merely a mimicry, a cheap imitation, a "lifelike mockery" (Constable), that opposed the "ideal form" and artistic skill, "those sights that ape the absolute presence of reality/Expressing, as in mirror, sea and land" as Wordsworth would have it (Wordsworth W Prelude, Book 7, 232-234) (D'Arcy Wood, 2001: 106107). In La Peau de Chagrin, Raphael leaves his "real life" and enters an ideal world: "leaving his real life behind, he rose by degrees into an ideal world, arrived in the enchanted palaces of Ecstasy" (Balzac, 2012: 15)

27 One can think of the case of the collector Beau-frère de Bonnier de la Mosson, depicted in his cabinet by Jacques de Lajoue (La boutique de l'apothicaire) (Mauriès, 2002: 186-187), combining the already worn iconology of the cabinet with the suggestion of vast and multiple spaces.

28 On the basis of this and other passages, Nathalie Preiss suggests that it is no coincidence that both cabinets, the literary one and the real one, were actually in the same street: Preiss, 2016b: 222.

29 Galdós, 36: "delirio simbolizado en la opulencia, verdadera estetica de millon."

\section{References}

Altick R (1978) The Shows of London. Harvard University Press: Cambridge, MA.

Ankersmit FR (2005) Sublime Historical Experience. Stanford University Press: Stanford, CA.

Balzac Hde (ed) (1959) Le Colonel Chabert. In: La Comédie humaine. Vol. 5. Éditions rencontre: Lausanne, Geneva, pp 25-94.

Balzac Hde (ed) (1967) Pierette. In: La Comédie humaine. Vol. 4 Gallimard Bibliothèque de la Pléiade: Paris, France, pp 3-163.

Balzac Hde (1976a) The Black Sheep. D. Adamson (transl.). Penguin Classics: London.

Balzac Hde (ed) (1976b) Le Cabinet des Antiques. In: La Comédie humaine. Vol. 4 Gallimard Bibliothèque de la Pléiade: Paris, France, pp 939-1096.

Balzac Hde (ed) (1976c) La Femme de trente ans. In La Comédie humaine. Vol. 2. Gallimard Bibliothèque de la Pléiade: Paris, France, pp 1037-1214.

Balzac Hde (ed) (1977) Ferragus. In: La Comédie humaine. Vol. 5. Gallimard Bibliothèque de la Pléiade: Paris, France, pp 793-903.

Balzac Hde (ed) (1978) Le Lys dans la vallée. In: La Comédie humaine. Vol. 9. Gallimard Bibliothèque de la Pléiade: Paris, France, pp 969-1229.

Balzac Hde (2009) Pere Goriot. A J. Krailsheimer (trans.). Oxford University Press: Oxford.

Balzac Hde (2009) Eugénie Grandet. S Raphael (trans.). Oxford University Press: Oxford.

Balzac Hde (2012) The Wild Ass' Skin; P. Coleman (trans.). Oxford University Press: Oxford.

Bann S (2011) Alternative Paradigms for the Historical Museum: Lenoir's Monuments français and Du Sommerard's Cluny. In: Poulot D, Bodenstein F and Lanzarote J M (eds). Great Narratives of the Past. traditions and Revisions in National Museums. EuNaMus Report No 4: Linköping University Electronic Press, pp 21-31.

Bauer D (forthcoming) Cromedeyre tout entier est une seule maison. The Domestic Interior in Jules Romains' Cromedeyre-le-vieil. In: Moran C (ed). The Domestic Interior in France and Belgium: Art, Literature and Design. Bloomsbury: London (forthcoming)

Bauer D (2016) Beyond the Frame. Case Studies. Academic and Scientific Publishers: Brussels, Belgium.

Bouvier J-C (1986) Frédéric Mistral et l'ethnographie selon Lou Trésor dóu Felibrige. Folklore; 39 (202-204): 5-17.

Davenne Ch (2004) Modernité du cabinet de curiosités. L'Harmattan: Paris, France. Degroff D (2012) Ethnographic Display and Political Narrative: The Salle de France of the Musée d'ethnographie du Trocadéro. In: Hopkin D and Baycroft T (eds) Folklore and Nationalism in Europe during the Long Nineteenth Century. Brill: Leiden-Boston, pp 113-135.

Delon M (1998) Le boudoir Balzacien. L’Année Balzacienne; 19, 227-254.

Delon M (1999) L'invention du boudoir. Zulma: Paris, France.

Dias N (2004) Le Musée d'ethnographie du Trocadéro, 1878-1908: anthropologie et muséologie en France. Centre nationale de la recherche scientifique: Paris, France.

Diaz J-L (2012) Balzac bric-à-brac. In: Le Magasin du XIXe siècle. Les choses. Vol. 2 , pp 86-93.

D'Arcy Wood G (2001) The Shock of the Real. Romanticism and Visual Culture, 1760-1860. Palgrave: New York.

Ebguy J-D (2004) Un "autre lieu". Territoires-Carrefours et personnages mobiles. Dans quelques scènes de la vie privée. In: Dufour Ph and Mozet N (ed). Balzac géographe. Territoires. Christian Pirot: Paris, France, pp 199-210.

Fritzsche P (2004) Stranded in the Present. Modern Time and the Melancholy of History. Harvard University Press: Cambridge and London.

Fröhlich J (1981) 'Le texte initial: la description du boudoir de Mme de Tillet dans Une fille d'Ėve', 2, L'Année Balzacienne, pp 205-223.

Galdós PB (2011) La Sombra. Eneida: Madrid, Spain

Galtier Ch (1977) La Provence et Frédéric Mistral au Museon Arlaten. Cuénot: s.l., France.

Gautier J-J (ed) (2016) Honoré de Balzac, Architecte D’Intérieur. Somogy éditions d'Art: Paris, France.

Griener P (2010) La République de l'oeil. L'expérience de l'art au siècle des Lumières. Odile Jacob: Paris, France.

Haag S (2013) Meisterwerke der Kunstkammer Wien. Kunsthistorisches Museum Wien: Vienna, Austria.

Hamon Ph (1992) Expositions: Literature and Architecture in Nineteenth-Century France. University of California Press: Berkeley, Los Angeles, CA, Oxford, pp 173-174.

Heathcote O (2013) Le bureau comme sociotope Balzacien: du "Colonel Chabert" aux "Employés". L’Année Balzacienne; 14 (1): 309-325.

Koselleck R (1988) Vergangene Zukunft: Zur Semantik geschichtlicher Zeiten. Suhrkamp Verlag: Frankfurt am Main, German.

Kranz I (2012) Medium and Genre. Panoramatische Literatur als historiographisches Material in Walter Benjamin's Passagenarbeit. In Preiss N and Stiénon $\mathrm{V}$ (ed). Croqués par eux-mêmes. La société à l'épreuve du panoramique. Interférences Littéraires/ Literaire interferenties. Vol. 8, pp 27-41.

Landrin A (1889) Anciens costumes populaires français au palais du Trocadéro. La Nature: Revue des sciences et de leurs applications aux arts de lindustrie; 17 (853): 295-298. 
Marignan E (1896) Instructions pour la récolte des objets d'ethnographie du Pays arlésien. Musée arlésien d'ethnographie. Imprimerie Jouve: Arles.

Marrache-Gouraud M (2008) Scénographie de quelques collections de curiosités. In: Lestringant $\mathrm{F}$ Le théâtre de la curiosité. PressesUniversitaires de ParisSorbonne: Paris, France, p 139.

Mauriès P (1998) Vies remarquables de Vivant Denon. Gallimard: Paris, France.

Mauriès P (2002) Cabinets de curiosités. Gallimard: Paris, France.

Meisel M (1983) Realizations. Narrative, Pictorial and Theoretical Arts in Nineteenth Century England. Princeton University Press: Princeton, NJ.

Neefs J (2004) Territoires privés, territoires publics. In: Dufour Ph and Mozet N (eds). Balzac géographe. Territoires. Christian Pirot: Paris, France, pp 113-121.

Noël M-F (1987) Du Musée d'ethnographie du Trocadéro au Musée national des Arts et des Traditions populaires. Muséologie et ethnographie. RMS: Paris: 140-151.

Oettermann S (1980) Das Panorama. Die Geschichte eines Massenmediums. Syndikat: Frankfurt-am-Main, German.

O’Connor JR (1977) Balzac's Soluble Fish. Ediciones José Porrúa Turanzas: Madrid, Spain.

Pasquini P (1988) “Le Félibrige et les traditions.". Ethnologie française, nouvelle série; 18 (3): 257-266.

Preiss N (2016a) D'un cabinet l'autre. Le boudoir comme laboratoire. In: Gautier JJ (ed). Honoré de Balzac, Architecte D’Intérieur. Somogy éditions d'Art: Paris, France, pp 173-189.

Preiss N (2016b) La curiosité n'est pas un vilain défaut. La cabinet de curiosités. In: Gautier J-J (ed). Honoré de Balzac, Architecte D'Intérieur. Somogy éditions d'Art: Paris, France, pp 217-237.

Richard J-P (ed) (1970) Corps et décors chez Balzac. In: Études sur le romantisme. Seuil: Paris, France, pp 5-139.

Richer JF (2004) L'économie matérielle d'un territoire de la vie privée dans la Comédie humaine. In: Dufour $\mathrm{Ph}$ and Mozet $\mathrm{N}$ (ed). Balzac géographe. Territoires. Christian Pirot: Paris, France, pp 193-198.

Richer JF (2012) Les boudoirs dans l'œuvre d'Honoré de Balzac. Surveiller, mentir, désirer, mourir. Éditions nota bene: Quebec, Canada.

Spiegel R (2000) Dominique-Vivant Denon et Benjamin Zix. Témoins et acteurs de l'épopée napoléonienne. L'Harmattan: Paris, France.

Trébosc D (2008) Ordre d'exposition et représentation du savoir. In: Lestringant $\mathrm{F}$ (ed). Le théâtre de la curiosité. Presses de l'Université Paris- Sorbonne: Paris, France, pp 67-75.
Vannier B (1972) L'inscription du corps. Pour une sémiotique du portrait Balzacian. Éditions Klincksieck: Paris, France.

Watson J (2000) Literature and Material Culture from Balzac to Proust: the Collection and Consumption of Curiosities. Cambridge University Press: Cambridge, UK.

Wells HG (2005) The Time Machine. Penguin Classics: London.

Witthaus JH (2013) Raum der Überreste. Zur literarischen Inszenierung des Zeit-Raums bei Balzac. In: Hertrampf $M$ and Schmelzer D (ed). Die Neuvermessung romantischer Räume: Raumkonzepte der französischen Romantik vor dem Hintergrund des "spatial turn". Frank \& Timme: Berlin, Germany, pp 221-243.

\section{Data availability}

Data sharing is not applicable to this article.

\section{Additional information}

Competing interests: The author declares that there are no competing interests.

Reprints and permission information is available at http://www.palgrave-journals.com/ pal/authors/rights_and_permissions.html

How to cite this article: Bauer D (2017) Interior spaces as traces in Balzac's La Comédie humaine. Palgrave Communications. 3:17043 doi: 10.1057/palcomms.2017.43.

Publisher's note: Springer Nature remains neutral with regard to jurisdictional claims in published maps and institutional affiliations

\section{(c) (1)}

This work is licensed under a Creative Commons Attribution 4.0 International License. The images or other third party material in this article are included in the article's Creative Commons license, unless indicated otherwise in the credit line; if the material is not included under the Creative Commons license, users will need to obtain permission from the license holder to reproduce the material To view a copy of this license, visit http://creativecommons.org/licenses/by/4.0/

(C) The Author(s) 2017 